\title{
Morphological diversity of culturable cyanobacteria from habitats in Segara Anakan, Central Java, Indonesia
}

\author{
SITI GIA SYAUQIYAH FITRI ${ }^{1,2, v}$, SUTARNO ${ }^{1, \text {,v }}$, HERU SASONGKO ${ }^{3}$, HASBIYAN ROSYADI ${ }^{1}$, \\ MEI RATNASARI ${ }^{1}$, SAFIRA CHAIRUNISA ${ }^{1}$ \\ ${ }^{1}$ Department of Biology, Faculty of Mathematics and Natural Sciences, Universitas Sebelas Maret. Jl. Ir. Sutami 36A Surakarta 57126, Central Java, \\ Indonesia. Tel./fax.: +62-271-663375, `email: syauqiyahfitri@gmail.com, ^^nnsutarno@yahoo.com \\ ${ }^{2}$ Department of Biology Education, Faculty of Teacher Training and Education, Universitas Sultan Ageng Tirtayasa. Jl. Ciwaru Raya, Cipare, Serang \\ 42124, Banten, Indonesia \\ ${ }^{3}$ Department of Pharmacy, Faculty of Mathematics and Natural Sciences, Universirtas Sebelas Maret. Jl. Ir. Sutami 36A Surakarta 57126, Central Java, \\ Indonesia
}

Manuscript received: 6 July 2021. Revision accepted: 30 November 2021.

\begin{abstract}
Fitri SGS, Sutarno, Sasongko H, Rosyadi H, Ratnasari M, Chairunisa S. 2021. Morphological diversity of culturable cyanobacteria from habitats in Segara Anakan, Central Java, Indonesia. Biodiversitas 22: 5617-5626. Cyanobacteria are Gramnegative bacteria that can undertake oxygenic photosynthesis. This ancient group of microorganisms is ubiquitous, occurs in fresh water, marine, cold, hot, and terrestrial habitats. Can survive on a minimum requirement of light, carbon dioxide $\left(\mathrm{CO}_{2}\right)$, and water, and able to fix the atmospheric $\mathrm{N}_{2}$ are among of their unique characteristics. These have collectively offered these bio-agents as the precious bioresource for sustainable development. A variety of cyanobacterial strains promise further advances in biotechnology, including as an alternative source of energy. Before its final use, cyanobacteria undergo several necessary bioprocesses, including strain isolation and selection. This study aims to isolate and identify culturable-cyanobacteria from several habitats in Segara Anakan, Cilacap, Indonesia. The current study is an outset step to obtain potential and suitable agents for biofuel production. Morphological identification using light microscopy showed that cyanobacteria found in samples from different habitats varied. There are 39 cyanobacterial isolates obtained from freshwater, brackish water, and rhizosphere-mangrove soil habitats. Some cyanobacteria are unicellular (Order Chroococcales, Synechococcales, Pleurocapcales), the others are filamentous cyanobacteria (Order Oscillatoriales). These cyanobacteria grow well on BG-11 media. Numerous re-streakings on fresh medium and treatments of ampicillin and nystatin as antibiotic and antifungal, respectively, were carried out to obtain pure cultures. The classification of cultured cyanobacteria has been problematic and complicated. The polyphasic approach was applied to justify the taxonomic classification of the isolates. It is a combination of different methods based on modern molecular, cytomorphological, and ecological methods.
\end{abstract}

Keywords: Cyanobacteria, estuary, freshwater, mangrove, marine, Segara Anakan

\section{INTRODUCTION}

Cyanobacteria are previously known as cyanophytes, blue-green algae. They are among the most abundant and potent primary producers on Earth, responsible for primary productivity and nitrogen fixation. This ancient group of microorganisms comprises unicellular to multicellular prokaryotes. They possess chlorophyll $a$ and undertake oxygenic-photosynthesis associated with photosystems I and II. Cyanobacteria are commonly called cosmopolitan microorganisms, which means can be found in various ecological habitats. The prominent habitats of cyanobacteria are limnic and marine environments (Mur et al. 1999). However, they occur in freshwater, marine, cold, hot, and terrestrial habitats. Several studies showed that cyanobacteria live as plankton in waters (Joseph 2005; Nedumaran et al. 2008), as benthos in sediments (Kyaruzi et al. 2003; Silambarasan et al. 2012), and as an epiphyte in aerial roots of mangroves (Toledo et al. 1995; Nedumaran et al. 2008; Pérez-Estrada et al. 2012).

As an oxygenic-photosynthetic bacterium, cyanobacteria have several unique features, such as their ubiquity presence, short generation time, and capability to fix the atmospheric $\mathrm{N}_{2}$. Cyanobacteria can also easily survive on minimal light, carbon dioxide $\left(\mathrm{CO}_{2}\right)$, and water. They have high biomass yield, grow on non-arable lands and various water sources, generate biofuels and other valuable by-products, and reduce greenhouse gas emissions. These unique characteristics have collectively made cyanobacteria as the precious bioresource for sustainable development. Genetically engineered cyanobacteria have been devised with novel genes to produce several biofuels such as biodiesel, bio-hydrogen, bio-methane. Therefore, it opens new avenues for the generation of biofuels in an economically sustainable manner (Singh et al. 2016). Nevertheless, to date, microalgal, including cyanobacterial biofuels production has not transited into reality primarily due to economic competitiveness. Heimann (2016) mentioned that for targeted high-value bio-product markets, the cultivation of specific strains, which have the biochemical profile, yields, and productivities to meet required productivities, is a necessary aspect yet receiving little attention.

Segara Anakan is a large lagoon with a humid tropical climate comprised of the only large estuarine-mangrove forest left in Central Java. The lagoon water fluctuates due 
to water hydrodynamics and changes in the monsoon. The semidiurnal tides with seawater enter through two channels west and east of the island. Its western part is affected by the Citanduy, the fifth largest river in Java. The Segara Anakan Lagoon (SAL) consists of a shallow estuarine lagoon, fringing mangroves, adjacent rice fields, and rural settlements. Mangrove is one of the very productive coastal ecosystems. Mangrove provides a nutrient-rich habitat for many organisms, including cyanobacteria, as one of the nutrient providers in the mangrove ecosystem (Kathiresan and Bingham 2001). Unfortunately, some studies reported environmental issues regarding land conversion by various anthropogenic activities, which cause the high sedimentation process and expansion of mangrove vegetation in the lagoon area. Ardli and Wolff (2009) reported dynamic changes in land use and land cover in the SAL, mainly due to resource overexploitation, degradation and pollution through unsustainable land-use practices in the hinterland, and pollution from industry and households in the SAL ecosystem. Such conditions may influence the ecological conditions, and as a result, it can affect the biodiversity of its natural resources, such as phytoplankton, including cyanobacteria (Dewi et al. 2019).

This study aims to isolate and identify culturablecyanobacteria from several habitats which compose the SAL ecosystem. The exploration study was conducted to obtain various native strains with unique and superior properties. It is essential as an initial step to other advanced studies in applied biotechnology, including biofuel production.

\section{MATERIALS AND METHODS}

\section{Study area}

Sampling sites comprise of different habitats (mangrove soil, brackish water, freshwater, and marine) in the Segara
Anakan area, located in in the south-western part of Central Java $\left(108^{\circ} 46^{\prime}-109^{\circ} 05^{\prime} \mathrm{E} ; 7^{\circ} 34^{\prime}-7^{\circ} 48^{\prime} \mathrm{S}\right)$, west of Cilacap city, bordering to West Java, Indonesia (Pangandaran) (Figure 1). The sampling was carried out by random sampling method at three stations from each habitat. Soil samples were taken from the rhizosphere of mangrove vegetation areas in Places. In addition, the marine samples were taken at Teluk Penyu, freshwater samples were taken at Timong river, and brackish-water samples were taken at the lagoon area (Citanduy estuary, Pusaran Batu Kelir).

\section{Procedures}

\section{Sampling and isolation of Cyanobacteria}

Samples used in this study were collected from mangrove soil, estuary (brackish water), freshwater, and marine in Segara Anakan by random sampling method. Physiochemical parameters of samples, such as temperature, $\mathrm{pH}$, salinity, and light intensity, were observed and recorded in situ. Water and soil samples were collected in a sterile bottle and plastic, stored in a container, taken to the laboratory for another treatment.

Cyanobacteria from the soil, freshwater, and brackish water samples were isolated by plating them in a solid BG11 media. As the marine cyanobacteria were isolated using ASN-III media. The medium composition is listed in Table 1. The culture was incubated at $25 \pm 2{ }^{\circ} \mathrm{C}$ under continuous illumination $<500$ lux for 7-14 days. Numerous restreakings on fresh medium and treatments of ampicillin and nystatin, as antibiotic and antifungal, respectively, were applied to obtain a pure culture (Rippka et al. 1979). Morphological features of cyanobacteria were done by using a light microscope (Leica) and identified by several kinds of literature, including Rippka et al. (1979), Waterbury (2006), Castenholz (2001), and Komarek (2003).

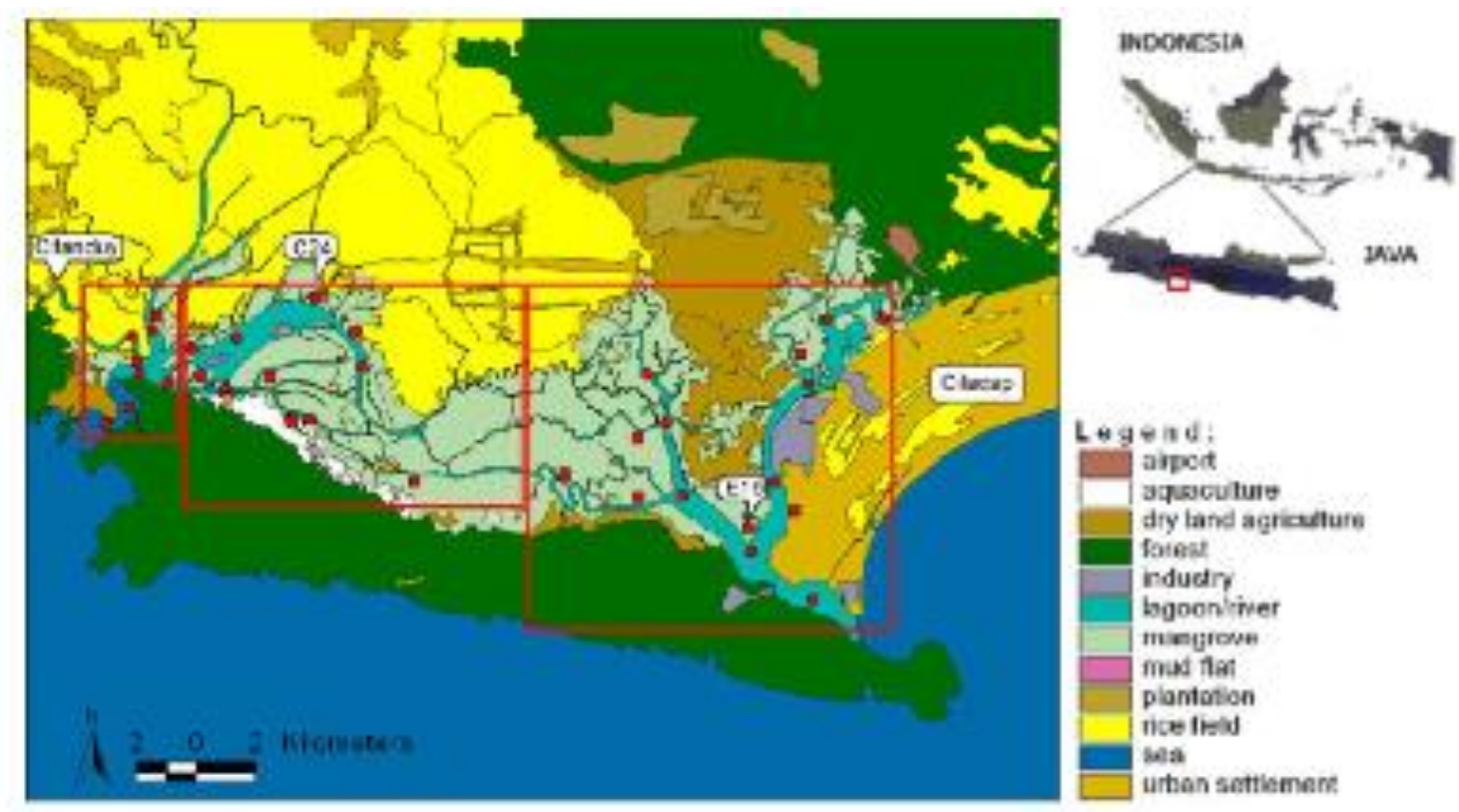

Figure 1. Location of Segara Anakan Lagoon, Cilacap District, Central Java, Indonesia (Nordhaus et al. 2018) 
Table 1. The composition of culture medium

\begin{tabular}{|c|c|c|}
\hline \multirow{2}{*}{ Component } & \multicolumn{2}{|c|}{ Culture medium (g/L) } \\
\hline & BG-11 & ASN-III \\
\hline $\mathrm{NaNO}_{3}$ & 1.5 & 0.75 \\
\hline $\mathrm{K}_{2} \mathrm{HPO}_{4}$ & 0.04 & 0.02 \\
\hline $\mathrm{MgSO}_{4} \cdot 7 \mathrm{H}_{2} \mathrm{O}$ & 0.075 & 3.5 \\
\hline $\mathrm{MgCl}_{2} \cdot 6 \mathrm{H}_{2} \mathrm{O}$ & - & 2.0 \\
\hline $\mathrm{CaCl}_{2} \cdot 2 \mathrm{H}_{2} \mathrm{O}$ & 0.036 & 0.5 \\
\hline $\mathrm{NaCl}$ & - & 25.0 \\
\hline $\mathrm{KCl}$ & - & 0.5 \\
\hline $\mathrm{Na}_{2} \mathrm{CO}_{3}$ & 0.02 & 0.04 \\
\hline Citric acid & 0.006 & 0.003 \\
\hline FeNH3-citrate & 0.006 & 0.003 \\
\hline Microelement solution *) & \multicolumn{2}{|c|}{$1 \mathrm{~mL}$} \\
\hline
\end{tabular}

\section{Morphological and molecular identification}

According to manufacturer instructions, genomic DNA extractions from 50-100 mg wet of a few cyanobacteria samples were conducted using Quick-DNA Fungal/ Bacterial Miniprep Kit (Zymo Research, D6005). Obtained genomic DNAs were amplified by 2x MyTaq HS Red Mix (BIO-25048), using universal bacterial primers for the $16 \mathrm{~s}$ gene region for all the cyanobacteria samples. The universal bacterial primer used has sequences for forward primer as 27F: 5'-AGA GTT TGA TCC TGG CTC AG-3' and for reverse primer as 1492R: 5'- GGT TAC CTT GTT ACG ACT T-3'.

The 16s rRNA gene regions' PCR products were sequenced using ABI PRISM 3730xl Genetic Analyzer developed by Applied Biosystems, USA and BigDye ${ }^{\circledR}$ Terminator v3.1 Cycle Sequencing Kit. Additional sequences for further phylogenetic analyses were acquired from GenBank (https://www.ncbi.nlm.nih.gov/genbank/).

\section{RESULTS AND DISCUSSION}

Sampling and physiochemical parameters of the sites

Segara Anakan has a tropical and humid climate. The observation of physiochemical parameters of the sites shows the different results for each habitat (Table 2). Environmental parameters may influence cyanobacterial diversity, such as temperature, $\mathrm{pH}$, salinity, and light intensity.

\section{Morphological identification}

Prior to isolation on solid media in a laboratory, the water samples were observed under a light microscope to ensure the availability of cyanobacteria. As a result, cyanobacteria from Order Chroococcales, such as Synechococcus dan Synechocystis, were observed in freshwater samples (Figure 1). Morphological identification is based on Rippka et al. (1979) and Waterbury (2006). Order Chroococcales contains all unicellular or non-filamentous aggregates of cells held together by extracellular slime or sheath layers. This group reproduces by binary fission (family Chroococcaceae) and by budding (family Chamaesiphonaceae). Both Synechococcus and Synechocystis divide by binary fission and have thylakoids. On the other hand, Synechococcus is in one plane and has a cell diameter of $<3 \mu \mathrm{m}$. In contrast, Synechocystis divide into two or three planes and has coccoid cells, occurring singly, in pairs, or aggregates held together by amorphous capsular material.

Cyanobacteria assigned as Order Pleurocapcales are also observed in freshwater samples and, among them, identified as Dermocarpa and Myxosarcina (Figure 2). The Order Pleurocapsales comprises cyanobacteria that reproduce by forming small spherical cells (called baeocytes) through multiple fission. The unicellular genera of the Order divide exclusively by multiple fission. In other genera, cell aggregates are produced by binary fission, after which some or all of the cells in the aggregates undergo multiple fission and release baeocytes (Waterbury 2006). Cell characteristics of Dermocarpa are that it divides solely by multiple fission, and its baeocytes are motile. Myxosarcina also has motile baeocytes, but it divides by a combination of binary and multiple fission. Its baeocyte development, followed by repeated binary fission to produce a cubical aggregate of cells.

Table 2. Physiochemical parameters of several habitats in Segara Anakan Lagoon, Central Java, Indonesia

\begin{tabular}{|c|c|c|c|c|c|c|c|}
\hline \multirow{3}{*}{ Habitat } & \multirow{3}{*}{ GPS Coordinate } & \multicolumn{6}{|c|}{ Abiotic parameter } \\
\hline & & \multicolumn{2}{|c|}{ Temp. $\left({ }^{\circ} \mathrm{C}\right)$} & \multirow[t]{2}{*}{$\mathbf{p H}$} & \multirow[t]{2}{*}{$\begin{array}{c}\text { Salinity } \\
(\% / 00)\end{array}$} & \multirow[t]{2}{*}{$\begin{array}{c}\text { Water } \\
\text { clarity }(\mathbf{c m})\end{array}$} & \multirow[t]{2}{*}{$\begin{array}{c}\text { Light } \\
\text { Intensity }\end{array}$} \\
\hline & & water & air & & & & \\
\hline \multicolumn{8}{|l|}{ Freshwater } \\
\hline Station 1 & S $07^{\circ} 39.113^{\prime} ;$ E $108^{\circ} 48.983^{\prime}$ & 28.5 & 34.7 & 7.7 & 2 & 21.7 & 5179 \\
\hline Station 2 & S $07^{\circ} 39.138^{\prime} ;$ E $108^{\circ} 48.975^{\prime}$ & 29 & 33.6 & 7.8 & 3 & 23.4 & 1732 \\
\hline Station 3 & S $07^{\circ} 39.265^{\prime} ;$ E $108^{\circ} 48.906^{\prime}$ & 28.5 & 32.4 & 7.8 & 3 & 26.3 & 1306 \\
\hline \multicolumn{8}{|l|}{ Brackish water } \\
\hline Station 1 & S $07^{\circ} 40.761^{\prime} ;$ E $108^{\circ} 48.005^{\prime}$ & 27.7 & 29 & 7.9 & 20 & 19 & 7255 \\
\hline Station 2 & S $07^{\circ} 40.779^{\prime} ;$ E $108^{\circ} 47.980^{\prime}$ & 27.3 & 29.4 & 8 & 23.3 & 19 & 4347 \\
\hline Station 3 & S $07^{\circ} 40.821^{\prime} ;$ E $108^{\circ} 48.164^{\prime}$ & 27.3 & 29.4 & 8.1 & 21 & 40.7 & 3697 \\
\hline \multicolumn{8}{|l|}{ Marine water } \\
\hline Station 1 & S $07^{\circ} 45.611^{\prime}$; E $109^{\circ} 01.168^{\prime}$ & 29 & 33 & 8.7 & 78 & 124 & 4970 \\
\hline Station 2 & $\mathrm{~S} 07^{\circ} 45.874^{\prime} ; \mathrm{E} 109^{\circ} 02.068^{\prime}$ & 29 & 32.5 & 8.7 & 77 & 82 & 5228 \\
\hline Station 3 & S $07^{\circ} 45.796^{\prime} ;$ E $109^{\circ} 01.533^{\prime}$ & 29 & 33 & 8.8 & 75 & 106 & 4403 \\
\hline \multicolumn{8}{|c|}{ Rhizosphere-mangrove soil } \\
\hline Station 1 & S $07^{\circ} 41.051^{\prime} ;$ E $108^{\circ} 48.958^{\prime}$ & 29.2 & 30.7 & 6.3 & - & $>100 *)$ & 2185 \\
\hline Station 2 & $\mathrm{~S} 07^{\circ} 41.095^{\prime} ; \mathrm{E} 108^{\circ} 49.614^{\prime}$ & 27.2 & 35 & 6.4 & - & $>100 *)$ & 3823 \\
\hline Station 3 & S $07^{\circ} 40.950^{\prime} ;$ E $108^{\circ} 49.742^{\prime}$ & 26.2 & 31.1 & 6.6 & - & $>100 *)$ & 3199 \\
\hline
\end{tabular}

Note: *) Humidity 


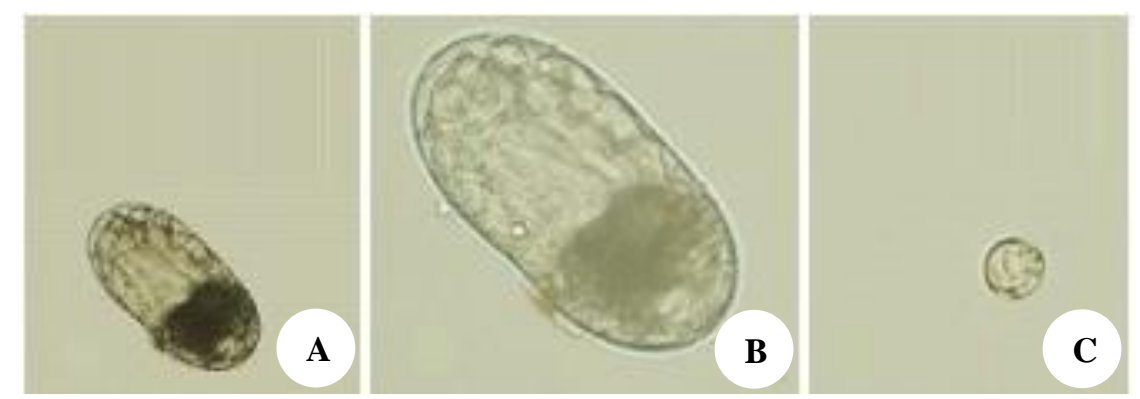

Figure 1. The Order Chroococcales, A-B. Synechococcus (100x dan 400x magnification); C. Synechocystis (400x magnification). Reference. Rippka et al. (1979)

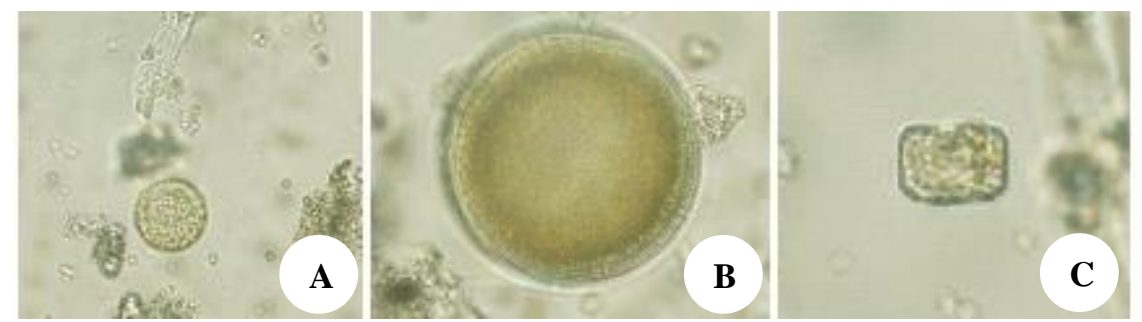

Figure 2. The Order Pleurocapcales, A-B. Dermocarpa (400x dan 1000x magnification); C. Myxosarcina (400x magnification). Reference. Rippka et al. (1979).

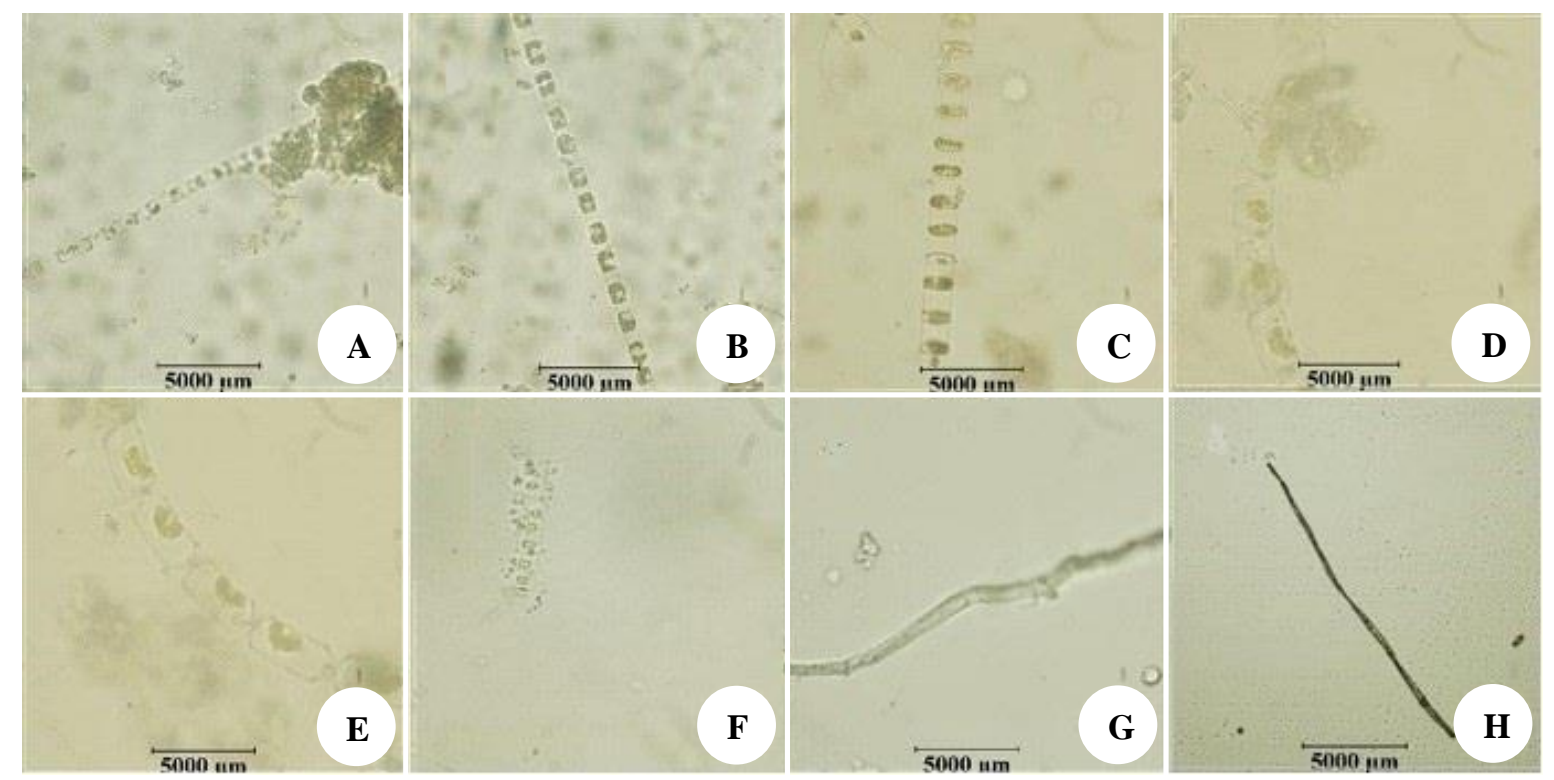

Figure 3. A-E. Filamentous Cyanobacteria found in brackish water sample; F-H. Filamentous Cyanobacteria found in the marine water sample

In samples of brackish water and seawater, various filamentous cyanobacteria cells are observed (Figure 3). They might belong either to the order Oscillatoriales or Nostocales (Rippka et al. (1979) and Waterbury (2006)). A further examination needs to be carried out to identify which genera the cell belongs to, i.e., trichomes (vegetative cells in the terminal of filament), the characteristics of extracellular sheath material, size, shape, and the arrangement of the cells within filaments. It is also essential to examine the presence or absence of heterocyst (specific cellular site of nitrogen fixation under aerobic conditions) and akinet (thick-walled resting cells).

\section{Isolation and cultivation of Cyanobacteria}

Cyanobacterial colonies isolated from freshwater, brackish water, and rhizosphere-mangrove soil grow well on the medium BG-11. However, marine cyanobacteria fail to grow on solid medium ASN-III. Some cultures have been pure, while others are still contaminated. Figure 4 
shows cyanobacterial colonies (green to yellowish color) grow on solid medium BG-11.

Observation on morphological features using light microscopy showed that the isolates are cyanobacteria. A total of 39 isolates are identified as unicellular or filamentous cyanobacteria. The unicellular cyanobacteria are assigned either as Order Chroococcales, Synechococcales, or Order Pleurocapsales. The filamentous cyanobacteria are assigned as Order Oscillatoriales. Figure 5. A and 5. B show 22 isolates from brackish water samples. Nine isolates from freshwater samples and eight isolates from rhizospheremangrove soil samples are shown in Figure 6 and Figure 7, respectively.

Identification of cyanobacterial isolates was carried out by using identification key from several kinds of literature, including Rippka et al. (1979), Waterbury (2006), Castenholz (2001), and Komarek (2003), as a guide. The unicellular cyanobacteria from brackish water were identified as Synechocystis (Figure 5. h, j, 1), Pleurocapsa group (Figure 5. c), Microcystis sp.1 (Figure 5. d and i), Aphanothece (Figure 5. p), Chroococcus (Figure 5. s), Microcystis sp. 2 (Figure 5. $\mathrm{m} 1$ and $\mathrm{m} 2$ ), and Gloeocapsa (Figure 5. v). The filamentous cyanobacteria were identified as LPP group B (Figure 5. n, r, t, and $\mathrm{u}$ ) and Leptolyngbya (Fig 5. a; Fig 5. o, and q).

Cyanobacteria isolated from freshwater habitats were mostly unicellular form. Based on morphological characteristics, these isolates were identified as Chamaesiphon sp.1 (Figure 6.b), Chroococcus (Figure 6.d), Cyanobacterium (Figure 6.e), Cyanothece (Figure 6g), Chamaesiphon sp.2 (Figure 6.h), and Microcystis (Figure 6f and i). The filamentous cyanobacteria were identified as LPP group B (Fig 6. a) and Planktolyngbya (Figure 6.c).

In this study, one isolate from rhizosphere-mangrove soil (station 1), identified as Synechococcus, is shown in Figure 7f. It shares the morphological properties of members assignable to the botanical genus Synechococcus Nägeli 1849. The cells are spherical- to rod-shaped, ranging from 0.6 to $2.1 \mu \mathrm{m}$ in diameter, containing peripheral photosynthetic thylakoids. The cells may be united into colonial aggregates by mucilage formation (Castenholz 2001). The genus is common in soil. Cells are solitary or in irregular groups or agglomeration. They do not form distinct colonies, have no slimy envelopes, or only a very fine, diffuse, and narrow gelatinous layer (Komarek 2003). Komarek (2016) assigned Synechococcus to family Synechococcaceae, Order Synechococcales.

Chroococcus sp. 1 (Figure 7. a), Synechocystis (Figure 7.b), Aphanothece sp. 1 (Figure 7.c), Microcystis (Figure 7e), Chroococcus sp.2 (Figure 7.g), and Aphanothece sp.2 (Figure 7.h) are found in rhizosphere-mangrove soil samples. The only filamentous cyanobacteria isolated from the soil habitat was identified as Lyngbya (Figure 7.d).

Molecular identification was carried on several isolates using the 16s rRNA gene sequence. PCR products $( \pm 1500$ $\mathrm{bp)}$ of the gene were analyzed by electrophoresis gel, as is shown in Figure 8. DNA sequencing analysis justifies the identification done based on morphology. Several isolates were confirmed by BLAST analysis on NCBI, as Leptolyngbya (accession no. MG822743.1), Microcystis (accession no. MT534588.1), Cyanobacterium (accession no. MK139949.1), and Cyanothece (accession no. KF157401.1).

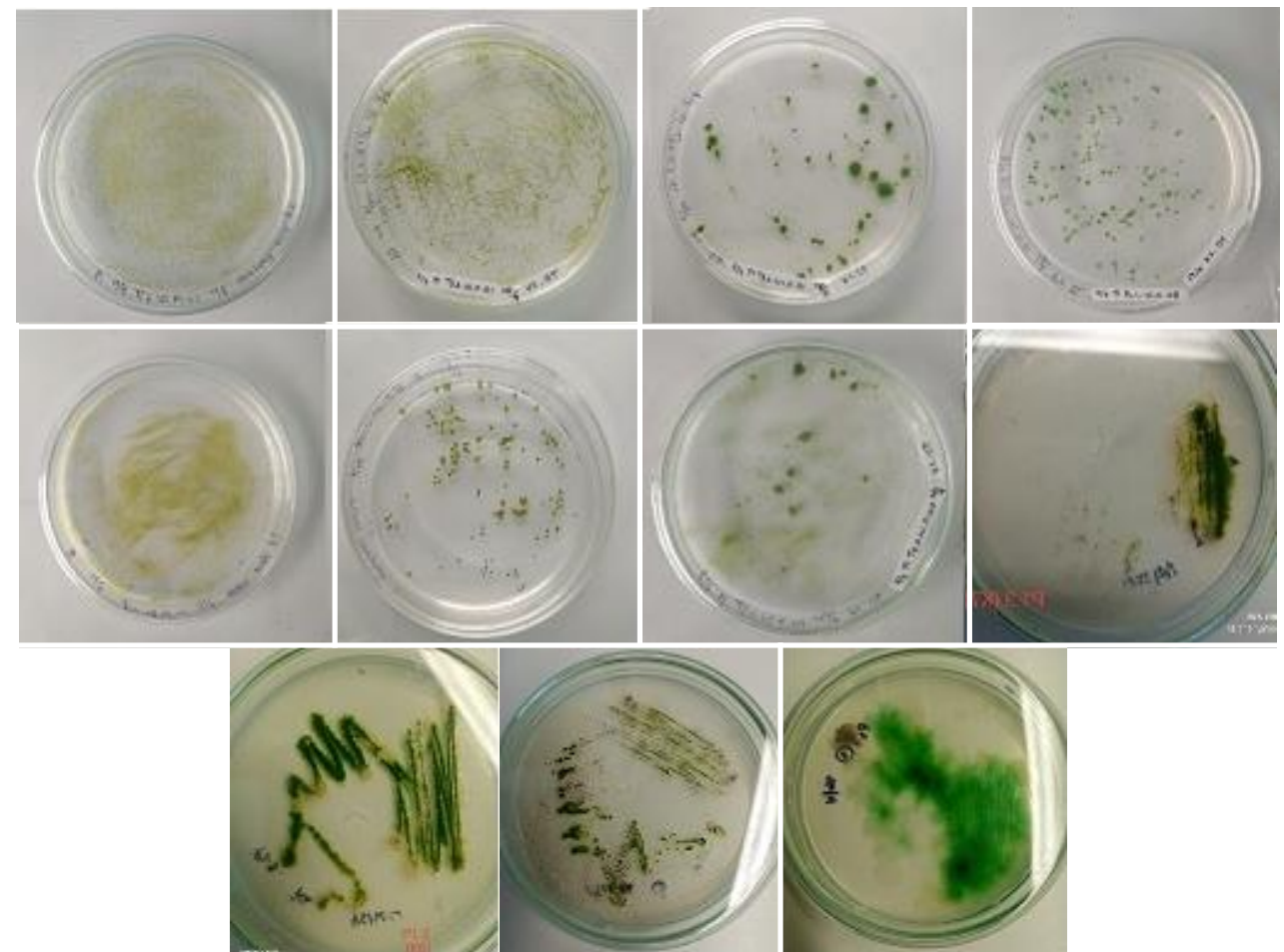

Figure 4. Cyanobacterial colonies growth on solid medium BG-11 


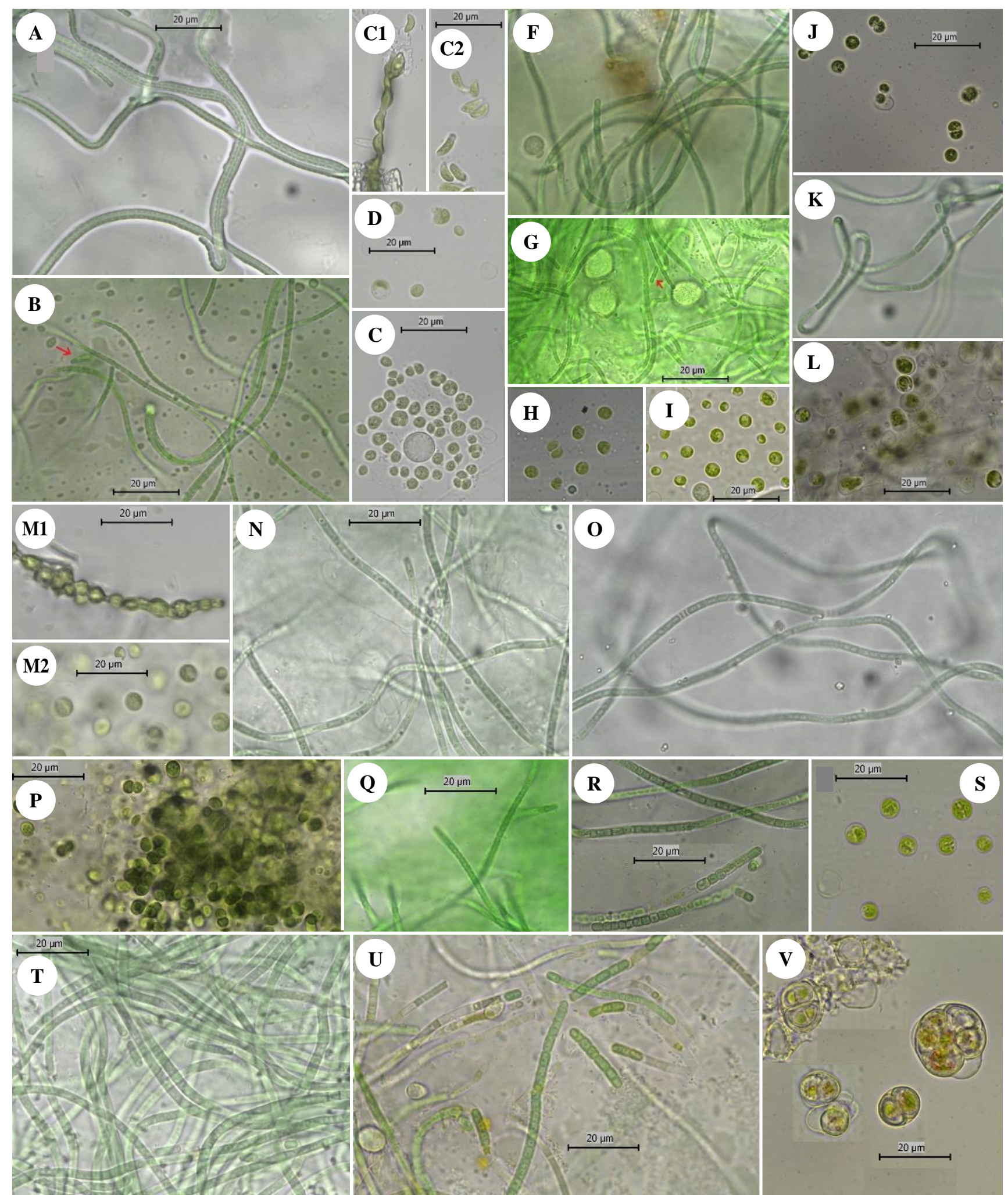

Figure 5. Isolates from brackish water habitat in Segara Anakan. A. Leptolyngbya; B. LPP group B; C. Pleurocapsa group; D. Microcystis; E. Chroococcus; F. Leptolyngbya; G-H. Synechocystis; I. Microcystis; J. Synechocystis; K. Leptolyngbya; L. Synechocystis, M1-M2. Microcystis; N. LPP group B; O. Leptolyngbya; P. Aphanothece; Q. Leptolyngbya; R. LPP group B; S. Chroococcus; T. LPP group B; U. LPP group B; V. Gloeocapsa 


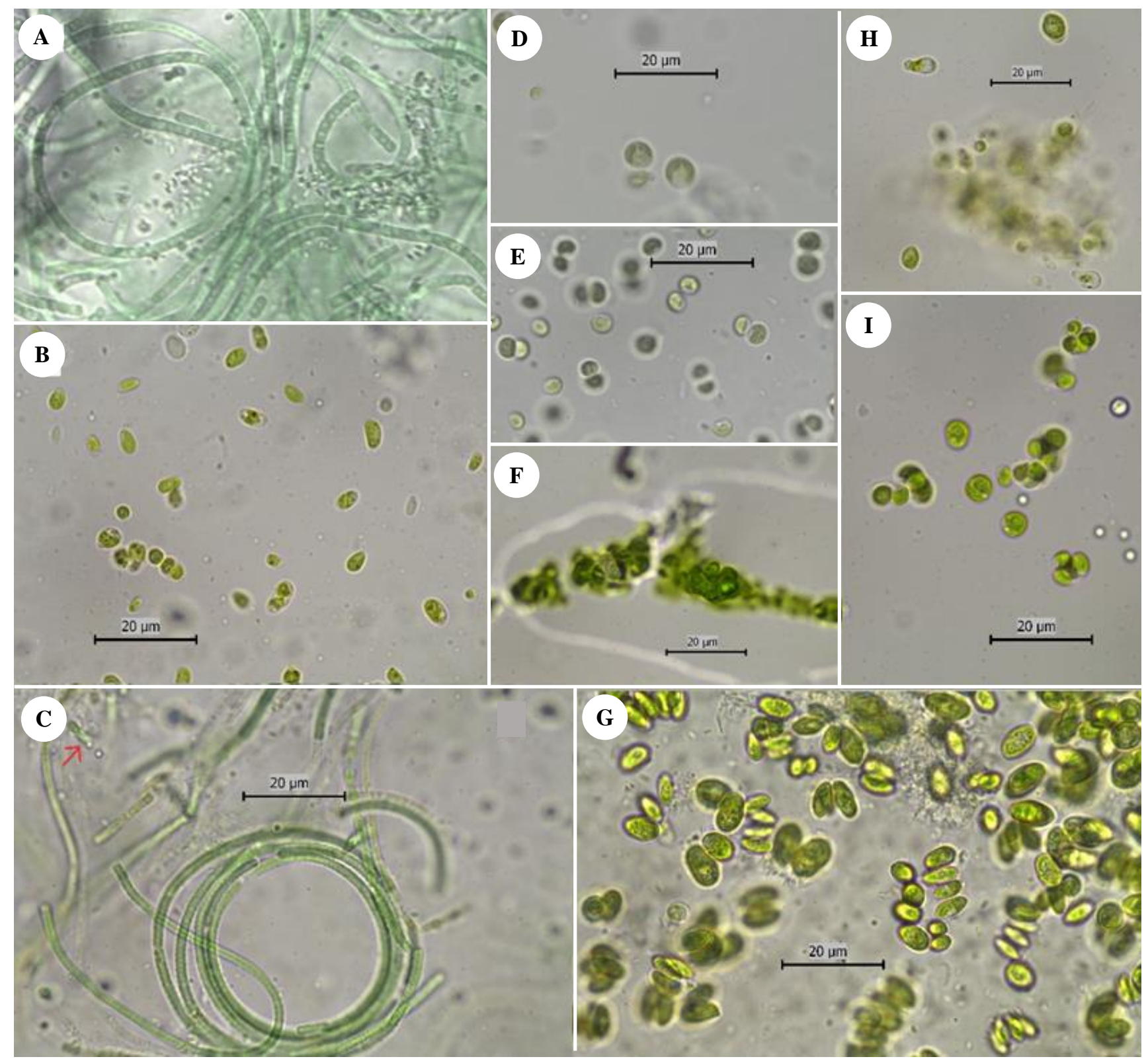

Figure 6. Isolates from freshwater habitat in Segara Anakan. A. LPP group B; B. Chamaesiphon sp.1; C. Planktolyngbya; D. Chroococcus; E. Cyanobacterium; F. Microcystis, G. Cyanothece; H. Chamaesiphon sp.2; I. Microcystis

\section{Discussion}

A thorough description of the sampling site is the first important step in isolating cyanobacteria. The site location and description, and parameters, such as light intensity, temperature, $\mathrm{pH}$, and salinity, should be recorded in situ. This information helps describe the natural habitat of the cyanobacteria to be isolated and can be critically important when designing culture media and conditions of incubation (Waterbury 2006). Media should be designed to emulate the chemical composition of the environment from which cyanobacteria are to be isolated. According to Rippka et al. (1979), medium BG-11 is widely used to isolate and maintain many cyanobacteria originating from freshwater, soil, or thermal and marine source materials. However, some marine cyanobacteria isolates are halo-tolerant and grow equally well on a medium with seawater or freshwater basis. Others have obligate sodium, magnesium, calcium, and chloride concentrations, which can only be fulfilled with seawater-based media, such as medium MN. As in this study, cyanobacteria collected from marine water failed to grow on medium ASN-III, which contains synthetic seawater. Hence, it is worth trying to grow it on a seawater-based medium.

Cyanobacteria are found in quite different temperature environments, ranging from freezing to $40^{\circ} \mathrm{C}$. Its optimum growth temperature is between $20^{\circ} \mathrm{C}$ and $35^{\circ} \mathrm{C}$. Naturally, cyanobacteria occur under a wide range of light conditions. However, they usually grow best when cultured at light intensities varying from $10-75 \mu \mathrm{Ein} \cdot \mathrm{m}-2 \cdot \mathrm{sec}-1$ supplied by warm- or cool-white fluorescent lamps or grown under 
continuous illumination Fluorescent White lamps, at relatively low intensity (<500 lux). Naturally, cyanobacteria have been cultured under constant illumination conditions. However, some cyanobacteria, such as non-heterocystous nitrogen fixers that temporally separate dinitrogen fixation and photosynthesis, require a light-dark cycle (Waterbury 2006). Higher intensities should be avoided since many strains (particularly those containing phycoerythrin) are light-sensitive (Rippka et al. 1979).

Many researchers studied the vital role of cyanobacteria in ecosystems and their potential as biological agents in various applications. Some studies explore the diversity of native and novel cyanobacterial strains from natural resources. Other studies focus on finding suitable, rapid, and effective methods for a cyanobacterial bio-products generation. For example, Rohmah et al. (2014) studied planktonic cyanobacteria from brackish water samples of Cagar Alam Pulau Dua (CAPD), Banten, Indonesia. They found 13 genera of different orders, i.e., Chroococcus, Synechococcus, Merismopedia, Coelosphaerium, Myxosarcina, Chroococcidiopsis, Dermocarpa, Lyngbya, Oscillatoria, Spirulina, Phormidium, Nostoc, and Calothrix. Fatimahsari et al. (2014) collected nine genera of epiphytic-cyanobacteria from Avicennia marina pneumatophores in the CAPD mangrove ecosystem, namely Chroococcus, Aphanothece, Aphanocapsa, Myxosarcina, Oscillatoria, Microcoleus, Lyngbya, Phormodium, and Calothrix. Edwin et al. (2019) recovered 11 isolates affiliated with Chroococcales, Oscillatoriales, Pleurocapsales, and Nostocales, from Lake Magadi, an alkaline saline Lake in Kenya.

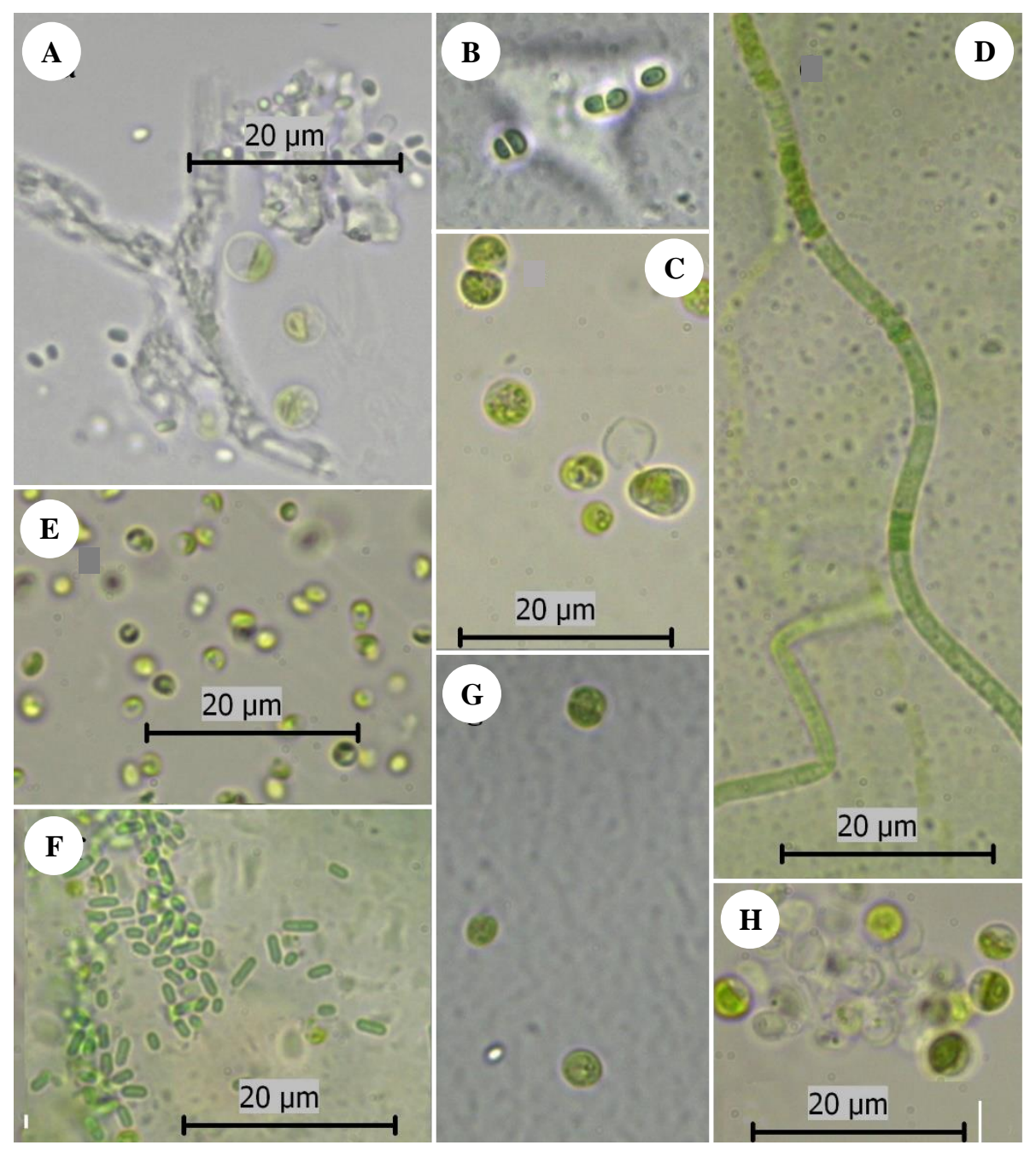

Figure 7. Isolates from mangrove rhizospherial soil in Segara Anakan. A. Chroococcus sp.1; B. Synechocystis; C. Aphanothece; D. Lyngbya; E. Microcystis; F. Synechococcus; G. Chroococcus sp.2; H. Aphanothece 

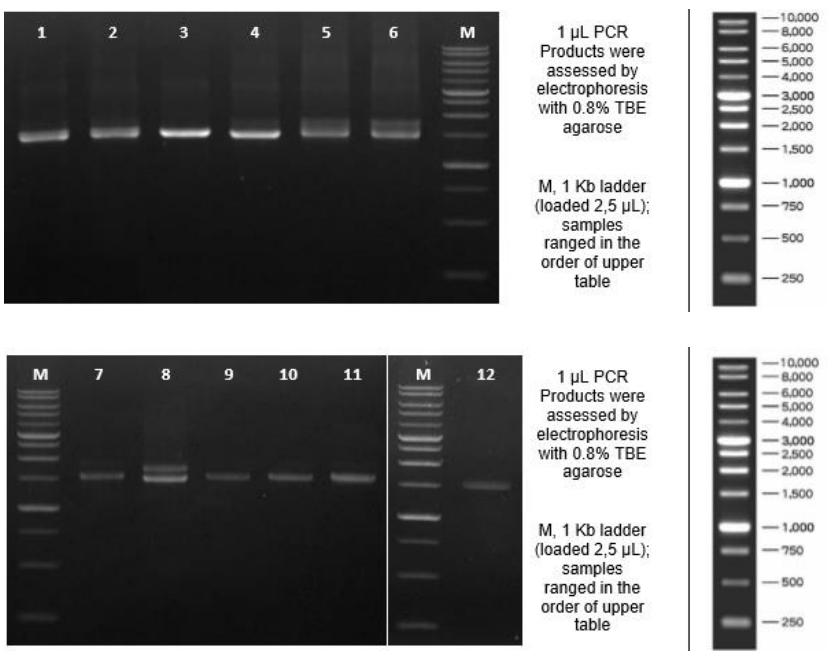

Figure 8. Gel electrophoresis result of 16s rRNA PCR product of cyanobacteria isolates

The culturable-cyanobacteria collected from habitat is usually under-estimated than the actual numbers. Moreover, many studies encounter difficulty in the isolation of axenic cultures of cyanobacteria. Some factors affect cyanobacteria cultivation, i.e., suitable medium, conditions of incubation, and isolation and purification methods. Temraleeva et al. (2016) declared that the stabinoculation technique on a solid nutrient medium could enrich cyanobacteria growth. It is because some cyanobacterial species grow poorly on the agar surface but develop nicely inside the agar.

Many purification methods are admitted to being rapid and efficient in separating cyanobacteria from fungi or other bacteria contaminants. These methods include ordinary plating procedures, such as numerous streaking on fresh mineral medium, treatments with antifungal/antibacterial, and mechanical separations, such as micro-manipulation, filtration, and equilibrium centrifugation. For example, Vaara et al. (1979) recognized that scoring the agar plate before incubation under unidirectional light is rapid and effective in separating gliding filamentous-cyanobacteria from contaminants. In addition, Varaa proposed obligate photoautotroph-cyanobacteria selected by culturing them in tryptone-yeast extract-glucose broth with cycloserine in darkness.

Waterbury (2006) mentioned that purification of unicellular cyanobacteria could be achieved by restreaking on solid media. Furthermore, he suggested transferring isolated colonies picked from agar plates into a liquid medium and to allow them to grow up before restreaking. Contaminants that are frequently found in cyanobacterial cultures are small heterotrophic bacteria. Thus, it is not an easy and rapid process to purify cyanobacteria; it requires diligence.

According to Komárek (2016), taxonomic classification is crucial for understanding and exploring knowledge about organismal diversity. However, the classification of cultured cyanobacteria has been problematic and complicated. Cyanobacteria consist of simple unicellular forms to multicellular types with a differentiated and diversified thallus. Their cells are cytologically relatively simple but variable in shape. Komárek proposes that combining different methods based on modern molecular, cytomorphological, and ecological methods is helpful to avoid a misleading classification. This polyphasic approach is considered a unique, modern, unambiguous, unequivocal, and entirely acceptable methodological procedure. However, it is rarely used nor possible for all known cyanobacterial populations.

However, in the traditional botanical treatments, morphological and developmental features form the basis for the description of taxa at the level of genera and above (Waterbury 2006). Recent research revealed an abundance of cryptic diversity evidenced by molecular analyses, most notably the 16S rRNA gene sequence. Many traditional genera have proven to be polyphyletic, but revisions are in process (Dvorak et al. 2017). Cyanobacteria exhibit a relatively high degree of morphological features compared to other prokaryotes. Morphology, the primary photosynthetic pigment, and molecular (phylogeny) are among of characteristics used to distinguish Cyanobacteria. Cyanobacteria were identified and categorized using morphological traits, such as cell dimensions, shape, color, type of branching, sheath characteristics, and cell contents.

Rashid et al. (2019) state that microalgae, including cyanobacteria, are convincing to be a tremendous potential biomaterial of performing environmental services and energy recovery to promote carbon-neutral bio-economy. Despite its tremendous potential, its large-scale application is facing challenges related to some technical and economic issues. Cyanobacteria undergo several necessary bioprocesses to attain their final use. The primary yet most crucial step of the bioprocesses is the isolation and selection of novel strains. Different characteristics of cyanobacteria may impact the quantity and quality of bioproduct obtained from the biomass. Therefore, according to Zahra et al. (2020), it is important to discover the right choice of material and its conversion to biofuel. Cyanobacteria are considered to have prominent potential as biofuel feedstock and may replace the majority of fossil fuel usage. They can accommodate the better biofuel production, economically and environmentally.

\section{ACKNOWLEDGEMENTS}

This research was funded by Hibah Penelitian Unggulan UNS (PU-UNS), Sebelas Maret University, Indonesia year 2020 .

\section{REFERENCES}

Ardli E, Wolff M. 2009. Land use and land cover change affecting habitat distribution in the Segara Anakan Lagoon, Java, Indonesia. Reg Environ Change 9 (4): 235-243. DOI: 10.1007/s10113-008-0072-6.

Castenholz RW. 2001. Oxygenic photosynthetic bacteria. In: Boone DR, Catenholz RW (eds) Bergey's Manual of Systematic bacteriology (2nd edition),.Springer-Verlag, New York.

Dewi R, Zainuri M, Anggoro S, Winanto T. 2019. A spatial-temporal analysis on the composition and abundance of phytoplankton in 
Segara Anakan Lagoon Area. IOP Conf Ser: Earth Environ Sci 406 012028.

Dvorak P, Casamatta DA, Hasler P, Jahodarova E, Norwich AR, A. Poulıckova. 2017. Diversity of the Cyanobacteria. In: Hallenbeck PC (eds) Modern Topics in the Phototrophic Prokaryotes. DOI: 10.1007/978-33.319.46261-5_1.

Edwin N, Akhwale JK, Mwirichia R. 2019. Phylogenetic and morphological diversity of culturable Cyanobacteria from Lake Magadi in Kenya. DOI: 10.33472/AFJBS.1.4.2019.24-31.

Fatimahsari TK, Fitri SG, Khastini RO. (2014). Epyphitic cyanobacteria on Avicennia marina pneumatophore in mangrove ecosystem of Cagar Alam Pulau Dua (Capd) Serang, Banten. In Proc Intl Conf Res Implementation Educ Math Sci: 177-182.

Heimann K. 2016. Novel approaches to microalgal and cyanobacterial cultivation for bioenergy and biofuel production. Curr Opin Biotechnol 38: 183-189. DOI: 10.1016/j.copbio.2016.02.024.

Joseph S. 2005. Ecological and biochemical studies on cyanobacteria of cochin estuary and their application as the source of antioxidants. [Thesis]. Department of Marine Biology, Microbiology, and Biochemistry, Cochin University of Science and Technology, Kochi, India.

Kathiresan K, Bingham BL. 2001. Biology of mangroves and mangrove ecosystem. Adv Mar Biol 40: 81-251. DOI: 10.1016/S00652881(01)40003-4.

Komárek J. 2003. Coccoid and Colonial Cyanobacteria. In: John DW, Robert GS (eds) Aquatic Ecology, Freshwater Algae of North America. Academic Press, Elsevier, Amsterdam. DOI: 10.1016/B978012741550-5/50004-0.

Komarek J. 2016. A polyphasic approach for the taxonomy of cyanobacteria: Principles and application. Eur J Phycol 51 (3): 346353. DOI: $10.1080 / 09670262.2016 .1163738$.

Komárek J, Kling H, Komárková J. 2003. Filamentous Cyanobacteria. In: John DW, Robert GS (eds) Aquatic Ecology, Freshwater Algae of North America. Academic Press, Elsevier, Amsterdam. DOI: 10.1016/B978-012741550-5/50005-2

Kyaruzi JJ, Kyewalyanga MS, Merauke MHS. 2003. Cyanobacteria composition and impact of seasonality on their in-situ nitrogen fixation rate in a mangrove ecosystem adjacent to Zanzibar Town. West Indian Ocean J Mar Sci 2 (1): 35-44. DOI: $10.4314 /$ wiojms.v2i1.28427.

Mur LR, Skulberg OM, Utkilen H. 1999. Cyanobacteria in the environment. In: Chorus I, Bartram J (eds) Toxic Cyanobacteria in Water: A guide to their public health consequences, monitoring, and management. WHO Publication.

Nedumaran. 2008. Mangrove-associated cyanobacteria at Pichavaram, Tamilnadu. Seaweed Res Util 30: 77-85.
Nordhaus I, Hadipudjana FA, Janssen R, Pamungkas J. 2009. Spatiotemporal variation of macrobenthic communities in the mangrovefringed Segara Anakan lagoon, Indonesia, affected by anthropogenic activities. Reg Environ Change 9 (4): 291-313. DOI: 10.1007/s10113009-0097-5.

Pérez-Estrada CJ, León-Tejera H, Serviere-Zaragoza E. 2012. Cyanobacteria and macroalgae from an arid environment mangrove on the East Coast of the Baja California Peninsula. Bot Mar 55: 187196. DOI: $10.1515 /$ bot-2012-0501.

Rashid N, Lee B, Chang Y. 2019. Recent trends in microalgae research for sustainable energy production and biorefinery applications. In: Alam Md A, Wang Z (eds) Microalgae Biotechnology for Development of Biofuel and Waste-water Treatment. Springer, Singapore. DOI: 10.1007/978-981-13-2264-8_1.

Rippka R, Deruelles J, Waterbury JB, Herdman M, Stainer RY. 1979. Generic assignment, strain histories, and properties of pure cultures of $\begin{array}{llllll}\text { Cyanobacteria. J Gen Microbiol } 110 & \text { (2): 1-61. DOI: }\end{array}$ 10.1099/00221287-111-1-1.

Rohmah WS, Fitri SGS, Khastini RO. 2014. Exploration of planktonic cyanobacteria in brackish waters of mangrove ecosystem at Cagar Alam Pulau Dua Serang-Banten. Prosiding Semirata 2014 Bidang MIPA. [Indonesian]

Silambarasan G, Ramanathan T, Kathiresan K. 2012. Diversity of marine cyanobacteria from three mangrove environments in Tamil Nadu Coast, South East Coast of India. Curr Res J Biol Scie 4 (3): 235-238.

Singh JS, Kumar A, Rai AN and Singh DP. 2016. Cyanobacteria: A precious bio-resource in agriculture, ecosystem, and environmental sustainability. Front Microbiol 7: 529. DOI: 10.3389/fmicb.2016.00529.

Temraleeva AD, Dronova SA, Moskalenko SV, Didovich SV. 2016. Modern methods for isolation, purification, and cultivation of soil $\begin{array}{lllll}\text { Cyanobacteria. } & \text { Microbiology } 85 & \text { (4): 389-399. DOI: }\end{array}$ $10.1134 /$ S0026261716040159.

Toledo G, Bashan Y, Soeldner A. 1995. Cyanobacteria and black mangroves in Northwestern Mexico: Colonization, and diurnal and seasonal nitrogen fixation on aerial roots. Can J Microbiol 41: 9991011. DOI: $10.1139 / \mathrm{m} 95-139$.

Vaara T, Vaara M, Niemela S. 1979. Two improved methods for obtaining axenic cultures of Cyanobacteria. Appl Environ Microbiol 38 (5): 1011-1014. DOI: 10.1128/aem.38.5.1011-1014.1979.

Waterbury JB. 2006. The Cyanobacteria-Isolation, Purification, and Identification. In: Dworkin M, Falkow S, Rosenberg, Schleifer KH, Stackebrandt E (eds) The Prokaryotes. Springer, New York. DOI: 10.1007/0-387-30744-3_38.

Zahra Z, Choo DH, Lee H, Parveen A. 2020. Cyanobacteria: Review of current potentials and applications. Environments 7 (2): 13. DOI: 10.3390/environments7020013. 